\title{
Expression and functional characterization of CD33 transcript variants in human acute myeloid leukemia
}

\author{
George S. Laszlo ${ }^{1}$, Kimberly H. Harrington ${ }^{1}$, Chelsea J. Gudgeon ${ }^{1}$, Mary E. Beddoe ${ }^{1}$, \\ Matthew P. Fitzgibbon ${ }^{2}$, Rhonda E. Ries ${ }^{1}$, Jatinder K. Lamba ${ }^{3}$, Martin W. McIntosh ${ }^{2}$, \\ Soheil Meshinchi ${ }^{1,4,5}$, Roland B. Walter ${ }^{1,6,7}$ \\ ${ }^{1}$ Clinical Research Division, Fred Hutchinson Cancer Research Center, Seattle, WA, USA \\ ${ }^{2}$ Public Health Sciences Division, Fred Hutchinson Cancer Research Center, Seattle, WA, USA \\ ${ }^{3}$ Department of Pharmacotherapy and Translational Research College of Pharmacy, University of Florida, Gainesville, FL, USA \\ ${ }^{4}$ Children's Oncology Group, Arcadia, CA, USA \\ ${ }^{5}$ Department of Pediatrics, University of Washington, Seattle, WA, USA \\ ${ }^{6}$ Department of Medicine, Division of Hematology, University of Washington, Seattle, WA, USA \\ ${ }^{7}$ Department of Epidemiology, University of Washington, Seattle, WA, USA
}

Correspondence to: Roland B. Walter, email: rwalter@fredhutch.org

Keywords: acute myeloid leukemia, antigen, CD33, immunotherapy, splice variants

Received: April 28, $2016 \quad$ Accepted: May 17, $2016 \quad$ Published: May 27, 2016

\section{ABSTRACT}

With the demonstration of improved survival of some acute myeloid leukemia (AML) patients with the CD33 antibody-drug conjugate, gemtuzumab ozogamicin (GO), CD33 has been validated as a target for antigen-specific immunotherapy. Since previous studies identified a CD33 splice variant missing exon 2 (CD33 ${ }^{\triangle E 2}$ ) and, consequently, the immune-dominant membrane-distal V-set domain, we investigated the expression and functional characteristics of CD33 transcript variants in AML. In primary AML specimens, we not only found full-length CD33 (CD33 ${ }^{\mathrm{FL}}$ ) and CD $33^{\triangle E 2}$ but also corresponding variants containing an alternate exon 7 predicted to encode a CD33 protein lacking most of the intracellular domain (CD33 ${ }^{67 a}$ and, not previously described, $C D 3^{\triangle E 2, E 7 a}$ ) in almost all cases. In acute leukemia cell sublines engineered to express individual CD33 splice variants, all splice variants had endocytic properties. CD $33^{\mathrm{FL}}$ and $\mathrm{CD} 33^{\mathrm{E7a}}$ mediated similar degrees of GO cytotoxicity, whereas CD $33^{\triangle \mathrm{EE}}$ and CD $33^{\triangle E 2, E 7 a}$ could not serve as target for GO. Co-expression of CD $33^{\triangle E 2}$ did not interfere with $\mathrm{CD} 33^{\mathrm{FL}}$ endocytosis and did not impact CD $33^{\mathrm{FL}}$-mediated $\mathrm{GO}$ cytotoxicity. Together, our findings document a greater-than-previously thought complexity of CD33 expression in human AML. They identify CD33 variants that lack exon 2 and are not recognized by current CD33-directed therapeutics as potential target for future unconjugated or conjugated antibodies.

\section{INTRODUCTION}

CD33, a member of the sialic acid-binding immunoglobulin (Ig)-like lectin (Siglec) family, is a $67 \mathrm{kD}$ single pass transmembrane glycoprotein with endocytic properties that is primarily expressed on normal multipotent myeloid precursors, unipotent colony-forming cells, and maturing granulocytes and monocytes [1]. CD33 is comprised of an amino-terminal variable (V)-set Ig-like domain mediating sialic acid binding followed by a $\mathrm{C} 2$-set Ig-like domain in its extracellular region, a transmembrane domain, and a cytoplasmic tail that contains 2 conserved tyrosine-based inhibitory signaling motifs. Upon phosphorylation, the latter provide docking sites for the recruitment and activation of the Src homology-2 (SH2) domain-containing tyrosine phosphatases SHP-1 and SHP-2 [1]. Increasing evidence suggests that CD33 and related Siglecs with inhibitory signaling motifs modulate inflammatory and immune responses through dampening of tyrosine kinase-driven signaling pathways [2]. For $\mathrm{CD} 33$, the precise physiological functions have remained unclear, but recently, genome-wide association studies 
have identified variants of CD33 as a major risk factor for Alzheimer's disease, suggesting an important role in neurodegeneration [2].

Restricted expression patterns render Siglecs appealing targets for antibody- and glycan-based therapeutics [3]. Consistent with its characteristic as a myeloid differentiation antigen, CD33 is expressed on at least a subset of malignant blasts in nearly all patients with acute myeloid leukemia (AML) and also, perhaps, in underlying leukemia stem cells in some cases $[1,4]$. There has therefore been a long-standing interest in the development of CD33-directed unconjugated and conjugated monoclonal antibodies for the treatment of AML. To date, gemtuzumab ozogamicin (GO), a humanized CD33 antibody conjugated to a calicheamicin- $\gamma_{1}$ derivative, has had the most success in the clinic. Several randomized trials have demonstrated that the addition of GO to induction chemotherapy reduces the relapse risk and improves survival of adults with newly diagnosed AML and favorable- or intermediate-risk features [5]. These studies are complemented by a large Children's Oncology Group (COG) trial of $>1,000$ pediatric patients in which GO reduced the relapse risk and improved event-free survival irrespective of the cytogenetic disease risk [6]. Although GO was withdrawn from the commercial market in most countries in 2010, these results have validated CD33 as therapeutic target in AML and have sparked renewed interest in CD33-directed immunotherapies [1].

UCSC genome browser and Ensembl databases contain 3 unique, validated CD33 transcript variants supported by at least one non-suspect mRNA sequence, NM_001772, NM_001082618 and NM_001177608. NM_001772 represents full-length CD33 (CD33 $\left.{ }^{\mathrm{FL}}\right)$ consisting of 7 coding exons and a 364 amino acid protein [7]. NM_001082618 skips exon 2 resulting in CD33 with a deleted exon $2\left(\mathrm{CD}_{3} 3^{\Delta \mathrm{E} 2}\right)$ and a 237 amino acid protein [8-11]. NM_001177608 uses an alternate exon 7, exon $7 \mathrm{a}\left(\mathrm{CD}_{3} 3^{\mathrm{E7a}}\right)$ [10], which is predicted to encode an early translational stop, resulting in a 310 amino acid protein with truncation of the 54 c-terminal amino acids of the intracellular domain relative to $\mathrm{CD} 33^{\mathrm{FL}}$. The existence of CD33 variants lacking exon 2 is relevant for therapeutic targeting of CD33 since the V-set domain, which is encoded by exon 2 , contains immune-dominant epitope(s) $[8,12]$ recognized by all currently clinically exploited CD33-directed therapeutics. Moreover, our previous studies in cell lines engineered to express mutant forms of CD33 demonstrated that CD33 endocytosis is largely limited and determined by the intracellular domain of CD33 and that changes in this domain significantly impact CD33 internalization [13-15]. It is therefore conceivable that transcript variants that lack most of the intracellular domain of CD33 differ in their endocytic properties from the wild-type protein. Here, we investigated to what degree CD33 transcript variants are found in AML, what the endocytic properties are of these variants, and whether their co-expression affects the ability of $\mathrm{CD} 33^{\mathrm{FL}}$ to serve as a target for therapeutic antibodies.

\section{RESULTS}

\section{Expression of CD33 splice variants in primary AML specimens}

To survey the pattern of CD33 splice variant expression in human AML, we took advantage of whole transcriptome RNA sequencing (RNAseq) data from 61 pre-treatment bone marrow and 7 peripheral blood specimens collected from pediatric patients with newly diagnosed AML. CD33 coding sequence splice junctions were filtered for junctions with $10 \%$ prevalence at a threshold of $\geq 10$ reads per specimen, resulting in 8 observed splice junctions (E1/E2, E1/E3, E2/E3, E3/E4, E4/E5, E5/E6, E6/E7a, E6/E7b; Figure 1A). These 8 splice junctions were consistent with the 3 known and wellsupported protein coding CD33 transcripts (NM_001772, NM 001082618, and NM 001177608; Figure 1B). Of the 8 junctions, 6 were shared by 2 or more known CD33 variants, whereas 2 were unique to one of two variants, NM_001082618 (E1/E3; specific for CD33 ${ }^{\triangle E 2}$ ) and NM_001177608 (E6/E7a; specific for CD33 ${ }^{\mathrm{E} 7 a}$ ). The latter 2 were found in 57/68 (85.3\%) and 55/68 (80.9\%) of the specimens (Figure 1C). The observed CD33 splice junctions in our RNAseq dataset also offered the possibility of a previously unknown fourth, distinct CD33 transcript that lacked exon 2 and used exon E7a instead of $\mathrm{E} 7 \mathrm{~b}\left(\mathrm{CD} 33^{\triangle \mathrm{E} 2, \mathrm{E} 7 \mathrm{a}}\right)$.

To further study CD33 variants in human AML and validate the findings obtained with RNAseq, we designed transcript-specific primers and used RT-PCR to assess expression of the $\mathrm{CD} 33^{\mathrm{FL}}, \mathrm{CD} 33^{\mathrm{AE} 2}, \mathrm{CD} 33^{\mathrm{E} 7 \mathrm{a}}$, and $\mathrm{CD} 33^{\triangle \mathrm{E} 2, \mathrm{E} 7 \mathrm{a}}$ transcripts in 29 pre-treatment specimens from adults with AML. Basic characteristics of these specimens are summarized in Table 1. In the majority of specimens (27/29 [93.1\%]), amplicons corresponding to the expected sizes of all 4 CD33 transcripts were found, whereas in the remaining 2 specimens $(6.9 \%$; samples \#14 and $\# 21)$, only 3 transcripts $\left(\mathrm{CD} 33^{\mathrm{FL}}, \mathrm{CD} 33^{\mathrm{AE} 2}\right.$, and $\left.\mathrm{CD} 33^{\mathrm{E} 7 \mathrm{a}}\right)$ were detectable (Figure 2). Three unique amplicons per CD33 transcript were subjected to Sanger sequencing to confirm the lack of exon 2 in CD33 $3^{\triangle \mathrm{E} 2}$, use of exon $7 \mathrm{a}$ in CD33 ${ }^{\mathrm{E7a}}$, and lack of exon 2 combined with use of exon $7 \mathrm{a}$ in $\mathrm{CD} 33^{\triangle \mathrm{E} 2, \mathrm{E} 7 \mathrm{a}}$; the latter sequence was subsequently deposited in GenBank (accession no. KX139463). In 7 cases, we had bone marrow specimens (containing AML cells) and paired peripheral blood specimens (without morphologic evidence of AML cells) available that were obtained on the same day. In all cases, the pattern of CD33 isoform expression was very similar in the peripheral blood and the marrow specimen, i.e. all CD33 isoforms could be identified in non-blast cells. 


\begin{tabular}{|c|c|c|c|}
\hline $\begin{array}{l}\text { Exon/exon } \\
\text { junction }\end{array}$ & $\begin{array}{l}\text { Transcripts represented by splice } \\
\text { junction }\end{array}$ & $\begin{array}{l}\text { AML specimens with } \\
\text { splice junction (\%) }\end{array}$ & $\begin{array}{c}\text { AML total reads } \\
\text { (reads/positive specimens) }\end{array}$ \\
\hline E1/E2 & NM_001772, NM_001177608 & $57 / 68(83.8)$ & $1215(21.3)$ \\
\hline E1/E3 & NM 001082618, CD33 $^{\triangle \mathrm{E2}, \text { E7a }}$ & $57 / 68(83.8)$ & $1064(18.7)$ \\
\hline E2/E3 & NM_001772, NM_001177608 & $65 / 68(95.6)$ & $2661(40.9)$ \\
\hline E3/E4 & all & $65 / 68(95.6)$ & $2836(43.6)$ \\
\hline E4/E5 & all & $68 / 68(100)$ & $3705(54.5)$ \\
\hline E5/E6 & all & $66 / 68(97.1)$ & $3852(58.4)$ \\
\hline E6/E7a & NM $001177608, C 3_{3}{ }^{\Delta E 2, E 7 a}$ & $55 / 68(80.9)$ & $439(8.0)$ \\
\hline E6/E7b & NM_001772, NM_001177608 & $65 / 68(95.6)$ & 3468 (53.4) \\
\hline
\end{tabular}

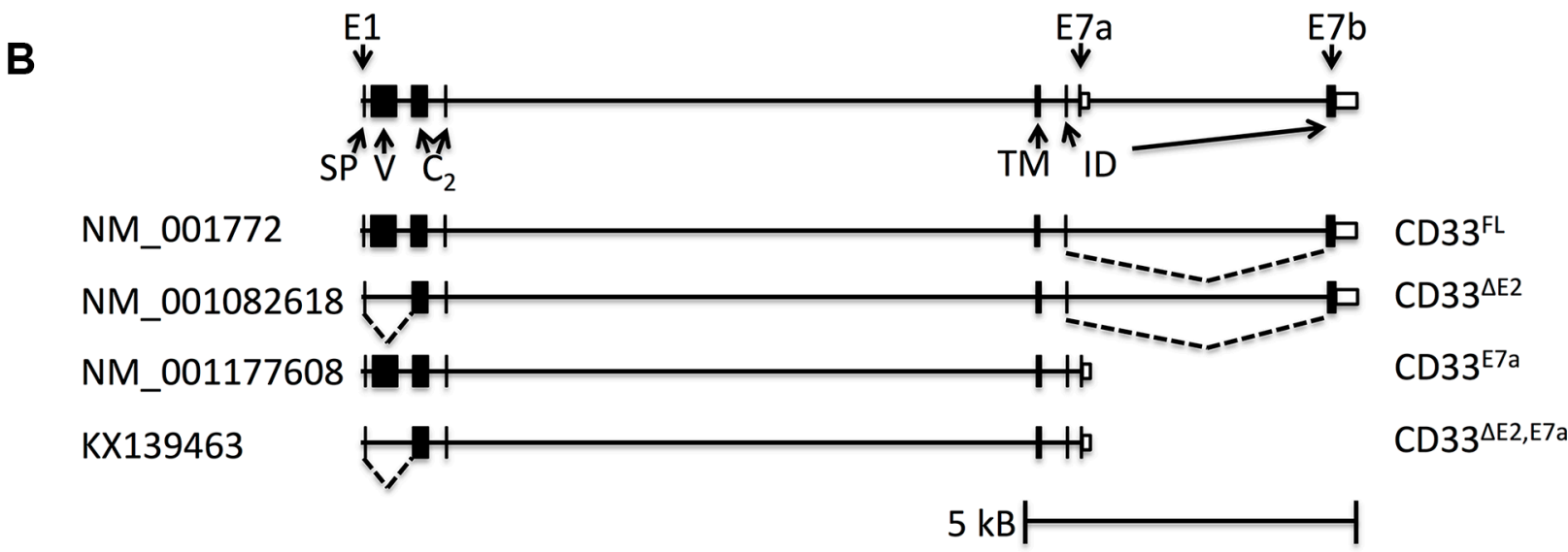

C

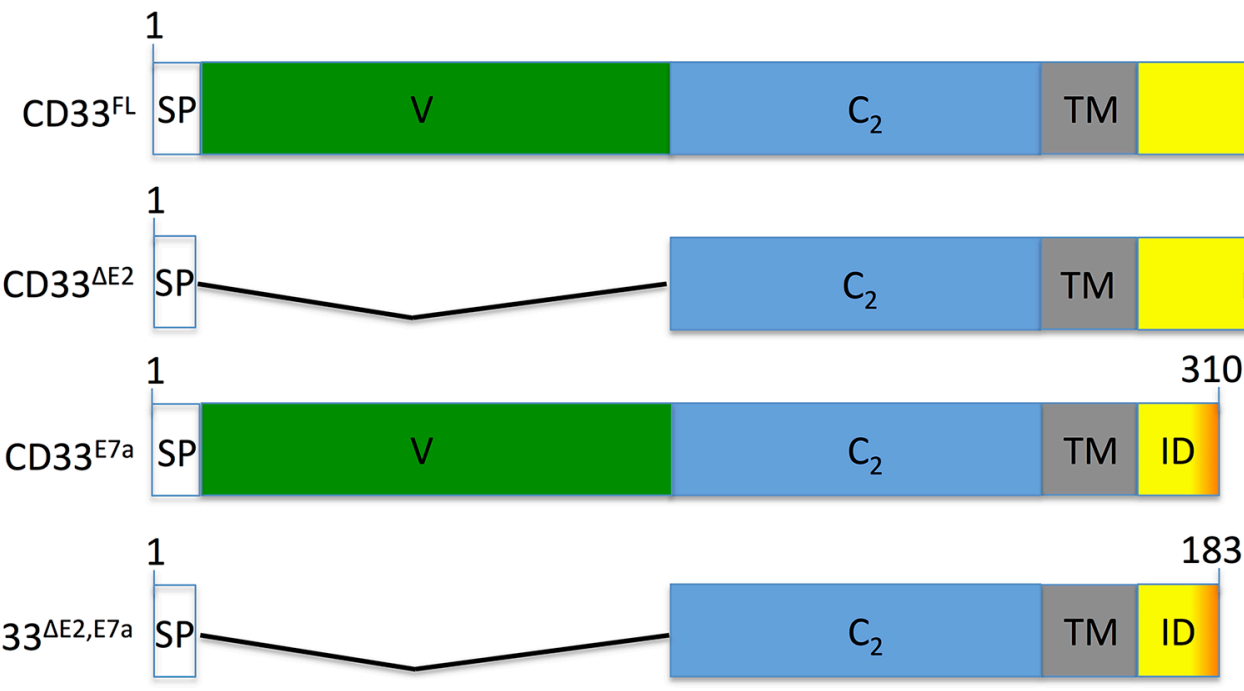

Figure 1: RNA sequencing to identify CD33 splice variants in human AML. (A) Summary of RNAseq results from 68 AML specimens, with provision of CD33 exon/exon boundaries (column 1) and known transcripts containing these specific exon/exon boundaries (column 2). Also indicated is the number of specimens with a positive read for each junction (columns 3 ) as well as total reads (columns 4). (B) Genomic structure of $\mathrm{CD}_{3} 3^{\mathrm{FL}}$ and $\mathrm{CD} 33$ splice variants. Located at chromosome $19 \mathrm{q} 13.41, \mathrm{CD}^{\mathrm{FL}}$ encodes an amino-terminus signal peptide (SP) of $16 \mathrm{AA}$ (exon 1), a sialic acid-binding amino-terminal V-set Ig-like domain (V, exon 2), a $\mathrm{C}_{2}$-set Ig-like domain ( $\mathrm{C}_{2}$, exon 3 and 4), a transmembrane domain (TM, exon 5), and an intracellular domain (ID, exon 6 and 7a or 7b). Besides CD33 $3^{\mathrm{FL}}$, RNAseq suggested our studies identified $3 \mathrm{CD} 33 \mathrm{mRNA}$ transcript variants, including two reported splice variants, CD $33^{\triangle \mathrm{E} 2}$ and $\mathrm{CD} 33^{\mathrm{E} 7 \mathrm{a}}$, and a previously unknown variant, $\mathrm{CD} 33^{\mathrm{\triangle E} 2, \mathrm{E} 7 \mathrm{a}}$. Skipped exons (dotted lines) and approximate location of variant specific primers are indicated. (C) Functional domains of $\mathrm{CD} 33^{\mathrm{FL}}$ and $\mathrm{CD} 33$ splice variants. CD33 ${ }^{\mathrm{AE} 2}$ lacks 124 amino acids encoded by exon 2 and, as a result, the V-set domain, while $\mathrm{CD} 33^{\mathrm{E} 7 \mathrm{a}}$ lacks 54 carboxy-terminal amino acids due to an early translation stop signal residing in exon 7a. CD33 ${ }^{\mathrm{AZ} 2 \mathrm{E} 7 \mathrm{a}}$ lacks both exon 2 and the 54 carboxy-terminal amino acids. Exon/exon boundaries were confirmed through gel extraction of PCR products shown, subsequent purification, and sequence analysis. 
Table 1: Basic characteristics of primary AML specimens used to study expression of CD33 splice variants by RT-PCR

\begin{tabular}{|c|c|c|c|c|c|c|c|c|}
\hline $\begin{array}{l}\text { Sample } \\
\#\end{array}$ & Age & $\begin{array}{c}\text { Disease } \\
\text { stage }\end{array}$ & Karyotype & $\begin{array}{c}\text { Cytogenetic } \\
\text { risk }\end{array}$ & $\begin{array}{l}\text { FLT3/ } \\
\text { ITD }\end{array}$ & NPM1 & Source & $\begin{array}{c}\text { Blasts } \\
(\%)\end{array}$ \\
\hline 1 & 68.90 & Refractory & $\begin{array}{l}\text { Hypodiploid with monosomy of } \\
\text { chromosome } 5,11,13 \text {, and } 17\end{array}$ & Adverse & Neg & $\mathrm{Neg}$ & PB & 86.9 \\
\hline 2 & 67.35 & Relapse & Normal & Intermediate & Pos & $\mathrm{Neg}$ & $\mathrm{BM}$ & 94.7 \\
\hline 3 & 65.30 & Relapse & Normal & Intermediate & Pos & Pos & $\mathrm{BM}$ & 89.2 \\
\hline 4 & 53.01 & Diagnosis & Normal & Intermediate & Pos & $\mathrm{Neg}$ & PB & 87.4 \\
\hline 5 & 71.52 & Relapse & Normal & Intermediate & Pos & $\mathrm{Neg}$ & $\mathrm{BM}$ & 82.0 \\
\hline 6 & 78.79 & Diagnosis & Normal & Intermediate & ND & ND & PB & 95.1 \\
\hline 7 & 63.00 & Diagnosis & $\begin{array}{l}46, \mathrm{XX}, \mathrm{t}(3 ; 5)(\mathrm{q} 21 ; \mathrm{q} 22) \\
{[9] / 46, \mathrm{XX}[11]}\end{array}$ & Intermediate & Neg & $\mathrm{Neg}$ & PB & 92.3 \\
\hline 8 & 67.14 & Relapse & Normal & Intermediate & Neg & Pos & $\mathrm{BM}$ & 79.4 \\
\hline 9 & 61.07 & Diagnosis & Normal & Intermediate & $\mathrm{Neg}$ & Pos & $\mathrm{BM}$ & 94.1 \\
\hline 10 & 78.03 & Diagnosis & $\begin{array}{l}\text { 46,XX,del(7)(q32) } \\
{[2] / 46, X X[19]}\end{array}$ & Adverse & Neg & Neg & $\mathrm{BM}$ & 90.9 \\
\hline 11 & 72.63 & Diagnosis & $\begin{array}{l}47, X Y, \operatorname{add}(1), \operatorname{del}(1) \\
(\mathrm{p} 22), \operatorname{add}(8), \operatorname{del}(16)\end{array}$ & Adverse & $\mathrm{Neg}$ & Neg & $\mathrm{BM}$ & 83.4 \\
\hline 12 & 79.30 & Diagnosis & Normal & Intermediate & ND & ND & $\mathrm{BM}$ & 65.1 \\
\hline 13 & 79.98 & Diagnosis & $\begin{array}{l}44, \mathrm{XX},-3,-5, \operatorname{add}(5)(\mathrm{p} 15) \\
\text { or del(5)(p13),inv(7) } \\
(\mathrm{p} 22 \mathrm{q} 11.2),+\mathrm{i}(11)(\mathrm{q} 10), \operatorname{add}(12) \\
(\mathrm{p} 13),-17[\mathrm{cp} 20]\end{array}$ & Adverse & ND & ND & $\mathrm{BM}$ & 58.7 \\
\hline 14 & 48.48 & Refractory & Normal & Intermediate & $\mathrm{Neg}$ & ND & PB & 89.4 \\
\hline 15 & 37.99 & Refractory & Normal & Intermediate & Neg & Pos & PB & 92.5 \\
\hline 16 & 23.92 & Diagnosis & $\begin{array}{l}46, X X, \operatorname{inv}(16)(\mathrm{p} 13 \mathrm{q} 22) \\
(17] / 47, \mathrm{sdl},+22[3]\end{array}$ & Favorable & Neg & $\mathrm{Neg}$ & PB & 92.2 \\
\hline 17 & 68.71 & Diagnosis & Normal & Intermediate & Pos & Pos & PB & 93.5 \\
\hline 18 & 73.77 & Diagnosis & $91, X X X X,-5, \operatorname{del}(6)(q 21 q 25)[20]$ & Adverse & $\mathrm{Neg}$ & Neg & $\mathrm{BM}$ & 86.5 \\
\hline 19 & 36.16 & Relapse & $47, \mathrm{XY},+8[20]$ & Intermediate & Pos & $\mathrm{Neg}$ & $\mathrm{BM}$ & 85.8 \\
\hline 20 & 54.43 & Diagnosis & 46,XY,inv(16)(p13.1q22)[20] & Favorable & $\mathrm{Neg}$ & $\mathrm{Neg}$ & PB & 92.5 \\
\hline 21 & 64.67 & Diagnosis & $\begin{array}{l}\text { 91,XXYY,del(5)(q23q31),del(6) } \\
\text { (q15q23),-7,del(7)(q31) } \\
{[10] / 94 \sim 99, \mathrm{sl},+6,+8,+9,+10,+13,} \\
+14,+19,+19,+20,+22,+0 \sim 1 \mathrm{mar}[ \\
\text { cp6]/46,XY[4] }\end{array}$ & Adverse & Pos & Neg & $\mathrm{BM}$ & 38.6 \\
\hline 22 & 66.51 & Diagnosis & Normal & Intermediate & Pos & Pos & $\mathrm{BM}$ & 93.2 \\
\hline 23 & 51.43 & Diagnosis & Normal & Intermediate & Pos & Pos & $\mathrm{PB}$ & 86.1 \\
\hline 24 & 69.10 & Refractory & Normal & Intermediate & Pos & Pos & PB & 87.1 \\
\hline 25 & 52.13 & Diagnosis & Normal & Intermediate & $\mathrm{Neg}$ & Neg & PB & 70.2 \\
\hline 26 & 40.16 & Diagnosis & Normal & Intermediate & Pos & Pos & PB & 75.2 \\
\hline 27 & 40.56 & Relapse & Normal & Intermediate & Pos & Pos & $\mathrm{PB}$ & 90.3 \\
\hline 28 & 55.69 & Refractory & Normal & Intermediate & Pos & ND & PB & 83.2 \\
\hline 29 & 48.30 & Refractory & $\begin{array}{l}46, X Y, t(11 ; 12)(q 13 ; p 13) \\
{[9] / 46, X Y[1]}\end{array}$ & Intermediate & $\mathrm{Neg}$ & Neg & PB & 87.4 \\
\hline
\end{tabular}

Abbreviations: BM, bone marrow; ND, not done; neg, negative; PB, peripheral blood; pos, positive. 


\section{Generation of cell line models to study CD33 splice variants}

Having demonstrated the presence of $\mathrm{CD} 33^{\triangle \mathrm{EE} 2}$, $\mathrm{CD} 33^{\mathrm{E7a}}$, and $\mathrm{CD} 33^{\triangle \mathrm{E} 2, \mathrm{E} 7 \mathrm{a}} \mathrm{mRNA}$ in primary human AML cells, we then studied the functional characteristics of encoded proteins. Therefore, we generated cell line models of human acute leukemia in which we selectively expressed untagged or His-tagged $\mathrm{CD} 33^{\mathrm{FL}}, \mathrm{CD} 33^{\mathrm{AE} 2}$, $\mathrm{CD} 33^{\mathrm{E} 7 \mathrm{a}}$ or $\mathrm{CD} 33^{\mathrm{EE2}, \mathrm{E} 7 \mathrm{a}}$ via lentivirus-mediated gene transfer, using a series of human AML (KG-1a, ML-1, and OCI-AML3) and acute lymphoblastic leukemia (ALL; RCH-ACV, REH, and RS4;11) cell lines. We used tagged versions of the $\mathrm{CD} 33$ proteins to distinguish those from endogenously expressed CD33 in some of these cell lines and to be able to track the $\mathrm{CD} 33^{\triangle \mathrm{E} 2}$ and $\mathrm{CD} 33^{\triangle \mathrm{E} 2 \mathrm{E} 7 \mathrm{a}}$ variants. While previous studies suggested that one CD33 antibody (clone Him3-4) specifically recognizes the $\mathrm{C}_{2}$ - set Ig-like domain and could be used to detect CD33 variants that lack exon 2 [9], in our experiments Him3-4 only recognized $\mathrm{CD} 33^{\mathrm{FL}}$ and $\mathrm{CD} 33^{\mathrm{E} 7 \mathrm{a}}$ but not $\mathrm{CD} 33^{\triangle \mathrm{E} 2}$ or $\mathrm{CD} 33^{\triangle \mathrm{E} 2, \mathrm{E} 7 \mathrm{a}}$ when expressed in virally-transduced ALL cell lines that are devoid of endogenous CD33 (Jurkat, RCH-ACV, REH, or RS4;11: Figure 3) and only recognized $\mathrm{CD} 33^{\mathrm{FL}}$ but not $\mathrm{CD} 33^{\triangle \mathrm{E} 2}$ when expressed in virally-transduced HEK293T cells (Figure 4). As shown in Figure 5, engineered sublines expressed high amounts of $\mathrm{CD} 33^{\mathrm{FL}}$ and $\mathrm{CD} 33^{\mathrm{E} 7 \mathrm{a}}$ in all cell lines. Lentivirus-mediated gene transfer also resulted in readily detectable cell surface display of the $\mathrm{CD} 33^{\triangle \mathrm{EE} 2}$ and $\mathrm{CD} 33^{\mathrm{\triangle E} 2 \mathrm{E} 7 \mathrm{a}}$ splice variants, although the level of expression varied considerably across cell line backgrounds.

\section{Internalization of CD33 splice variants in human leukemia cell lines}

As the first characteristic, we studied the endocytic properties of the CD33 splice variants when engaged by bivalent antibodies. To test whether the internalization of antibody-bound CD33 differed depending on the type of antibody used (i.e. His antibody vs. CD33 antibody), we compared the 120- and 240-minute internalization of CD33 in RCH-ACV and REH engineered to expressed untagged and His-tagged CD33 ${ }^{\mathrm{FL}}$. The studies showed very comparable rates of antibody uptake when studied with CD33 antibody in cells expressing untagged and Histagged $\mathrm{CD} 33^{\mathrm{FL}}$ or with His antibody in cells expressing His-tagged $\mathrm{CD} 33^{\mathrm{FL}}$, indicating that the His-tag does not interfere with the natural internalization properties of CD33 (Figure 6). Overall, our experiments in the panel

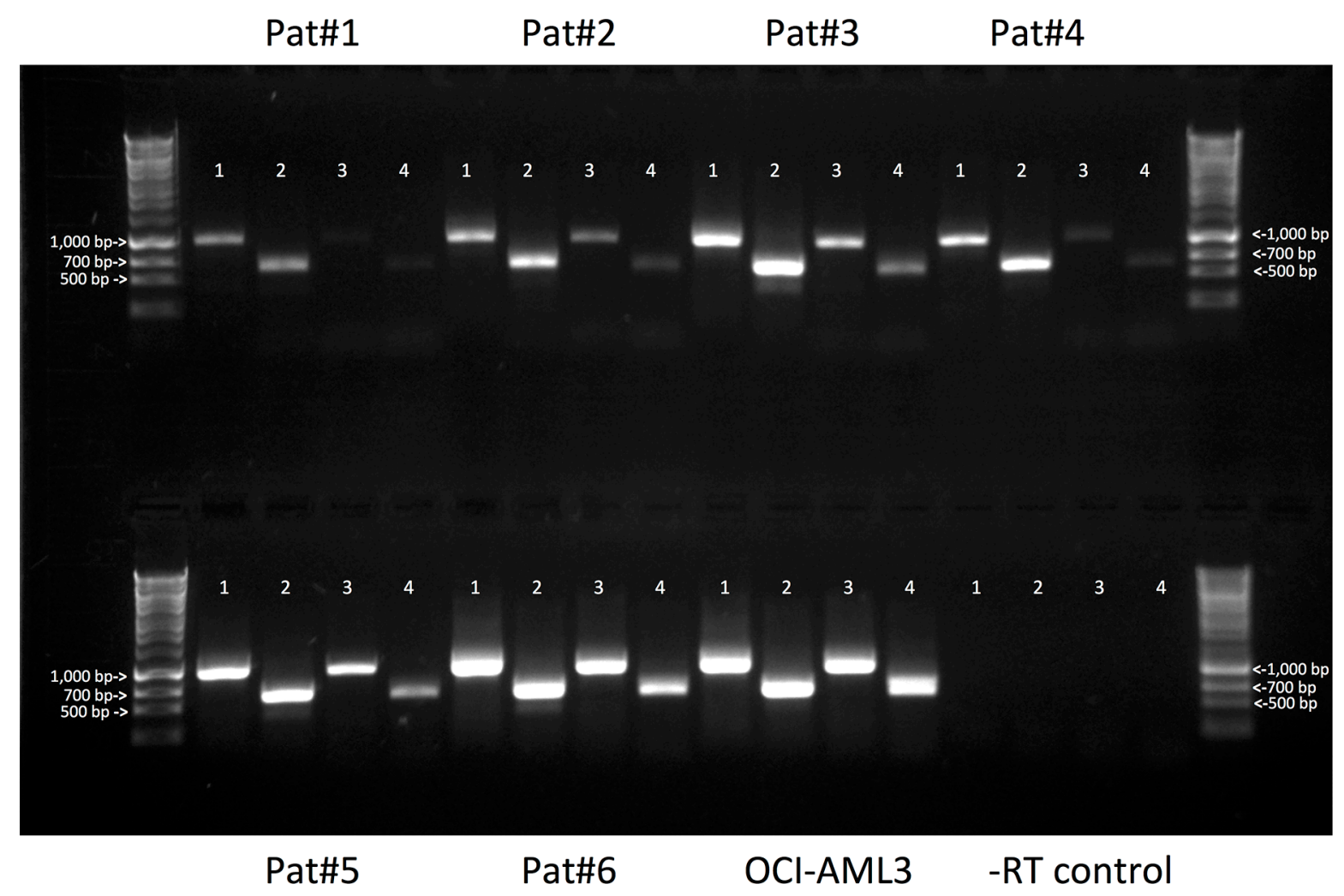

Figure 2: Expression of CD33 splice variants in primary AML specimens. Total RNA was isolated from 29 primary AML specimens and assayed for expression of mRNA for $\mathrm{CD} 33^{\mathrm{FL}}, \mathrm{CD} 33^{\triangle \mathrm{E} 2}, \mathrm{CD} 33^{\mathrm{E} 7 \mathrm{a}}$, and $\mathrm{CD} 33^{\mathrm{AE} 2 \mathrm{E} 7 \mathrm{a}}$, using variant-specific primers. Amplicons were electrophoretically separated in $0.9 \%$ agarose gel and visualized with ethidium bromide. Shown are results from 6 representative samples; also shown are a positive control (OCI-AML3 cells), a negative control (-reverse transcriptase [-RT]), as well as a sizing ladder. Lane 1: CD33 ${ }^{\mathrm{FL}}$ (expected amplicon size: $980 \mathrm{bp}$ ); lane 2: CD33 ${ }^{\mathrm{AE} 2}$ (expected amplicon size: $617 \mathrm{bp}$ ); lane 3: CD33 ${ }^{\mathrm{E} 7 \mathrm{a}}$ (expected amplicon size: $965 \mathrm{bp}$ ); and lane 4: CD33 ${ }^{\Delta \mathrm{E} 2 \mathrm{E} 7 \mathrm{a}}$ (expected amplicon size: $604 \mathrm{bp}$ ). 
of sublines of AML and ALL cells expressing Histagged CD33 spice variants demonstrated that each variant is internalized when bound by a bivalent His antibody (Figure 5). While, on average, the internalization properties of each variant appeared relatively similar, we noted some cell line-specific differences in the comparative uptake of individual CD33 splice variants. In particular, in ML-1 cells, internalization of the CD33 ${ }^{\mathrm{E} 7 \mathrm{a}}$ variant proceeded more slowly than that of the other CD33 molecules. Since some previous data have suggested that CD33 might form dimers on the cell surface in its physiologic state [16], we considered the possibility that $\mathrm{CD} 33^{\mathrm{AE} 2}$ could interfere with the functional properties of $\mathrm{CD} 33^{\mathrm{FL}}$. To test this idea, we compared the internalization of endogenous CD33 when bound with CD33 antibody in ML-1, OCI-AML3, and TF-1 cells that were lentivirally-transduced to also express CD33 ${ }^{\Delta \mathrm{E} 2}$ with that of non-transduced parental cells. These studies showed that uptake of endogenous CD33 was unaffected by the forced expression of the $\mathrm{CD} 33^{\triangle \mathrm{E} 2}$ splice variant (Figure 7). Finally, we also assessed the degree to which cell surface CD33 expression levels decreased with continued exposure to antibody ("CD33 modulation"). In 24-hour assays, we found some differences between individual CD33 variants in several acute leukemia cell lines; however, while highly reproducible, these
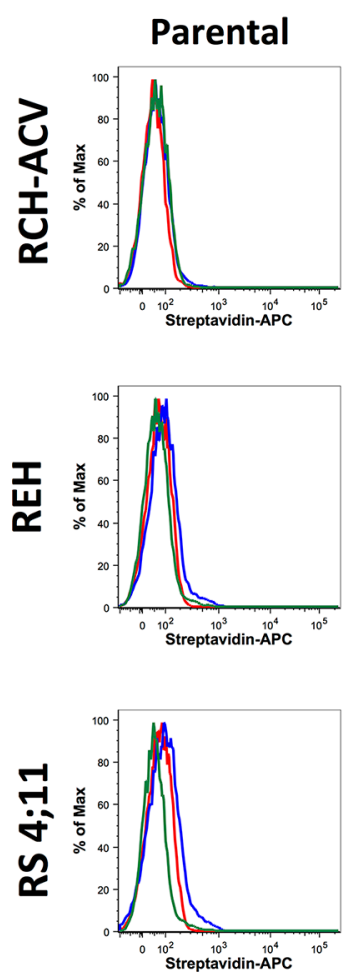

\section{$\mathrm{His}^{6}-\mathrm{CD} 33^{\mathrm{FL}}$}
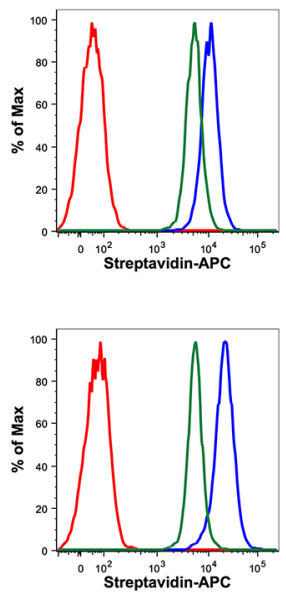

$\mathrm{His}^{6}-\mathrm{CD} 33^{\mathrm{LE2}}$

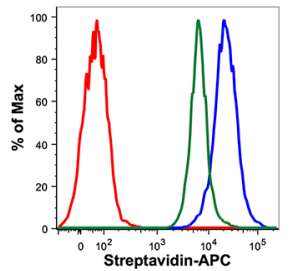

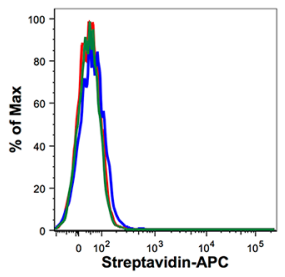
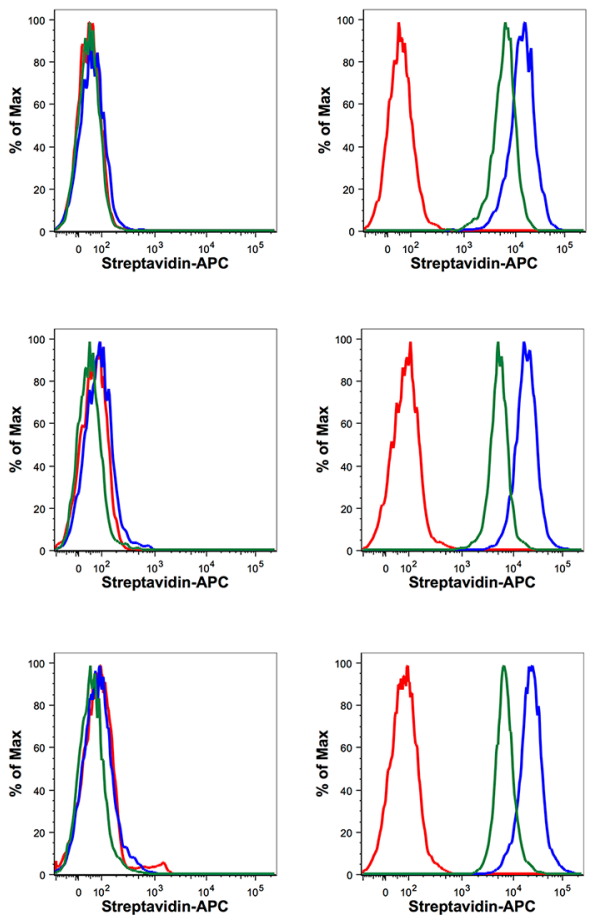

$\mathrm{His}^{6}-\mathrm{CD} 33^{\mathrm{E7a}}$

$\mathrm{His}^{6}-\mathrm{CD} 33^{\Delta \mathrm{E2}, \mathrm{E7a}}$
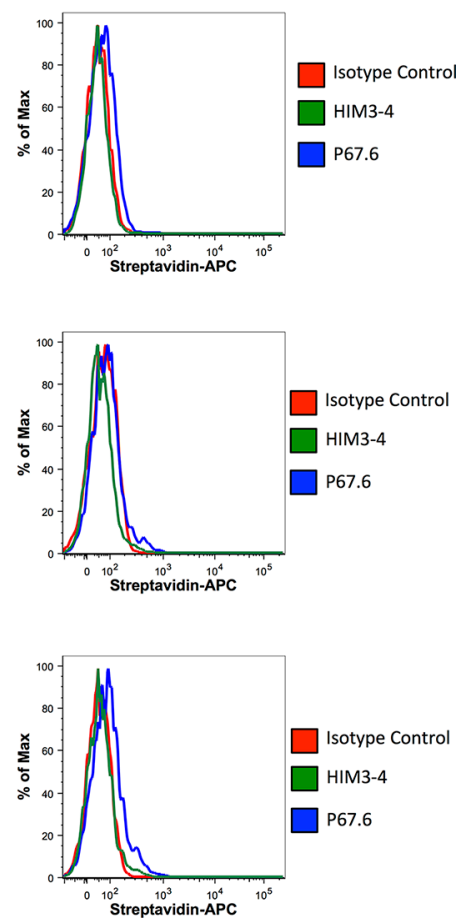

Figure 3: Phenotyping of acute leukemia cell lines with CD33 antibodies. Parental RCH-ACV, REH, and RS4;11 cells and their sublines transduced with His-tagged $\mathrm{CD} 33^{\mathrm{FL}}, \mathrm{CD} 33^{\mathrm{\triangle E} 2}, \mathrm{CD} 33^{\mathrm{E} 7 \mathrm{a}}$, or $\mathrm{CD} 33^{\mathrm{AE} 2 \mathrm{E} 7 \mathrm{a}}$ were incubated with HIM3-4, P67.6 or isotype control antibody followed by incubation with a biotin-anti-mouse secondary antibody and APC-streptavidin. Results are shown from one representative experiment.
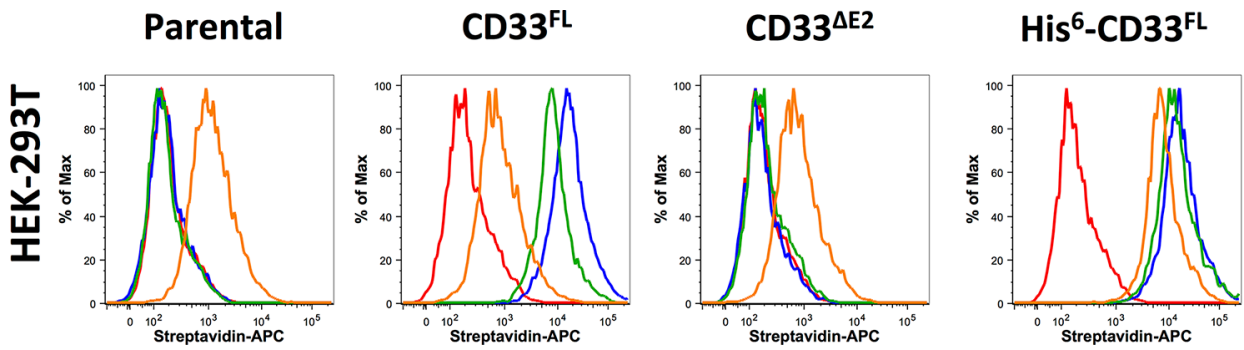

\section{His $^{6}-\mathrm{CD} 33^{\Delta E 2}$}

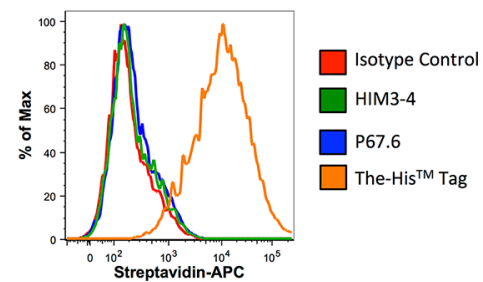

Figure 4: Phenotyping of engineered HEK293T cells with CD33 antibodies. Parental HEK293T cells and sublines transduced with untagged or His-tagged $\mathrm{CD} 33^{\mathrm{FL}}$ or $\mathrm{CD} 33^{\mathrm{AE} 2}$ were incubated with HIM3-4, P67.6, a His antibody, or isotype control antibody followed by incubation with a biotin-anti-mouse secondary antibody and APC-streptavidin. Results are shown from one representative experiment. 
A

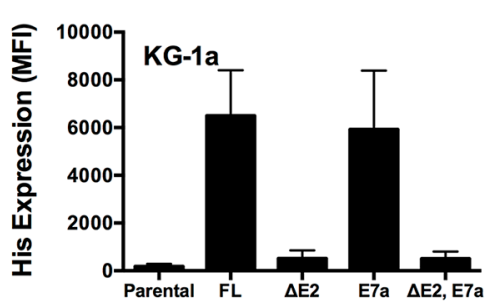

B

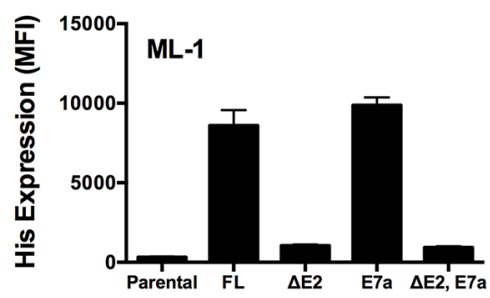

C

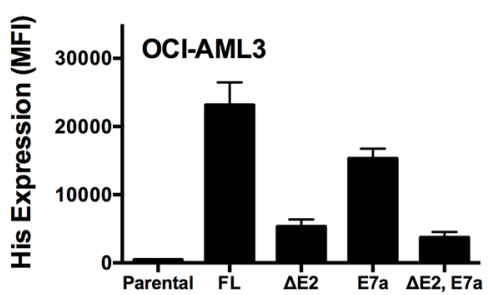

D

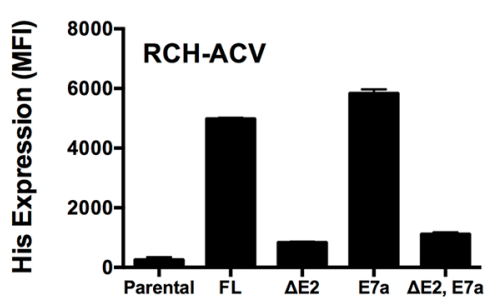

$\mathbf{E}$

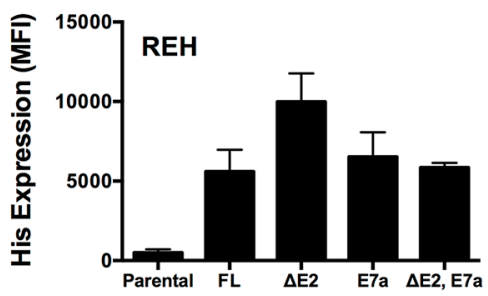

$\mathbf{F}$

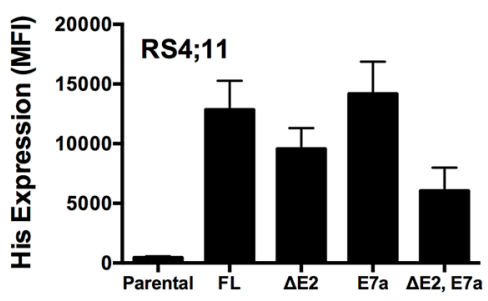

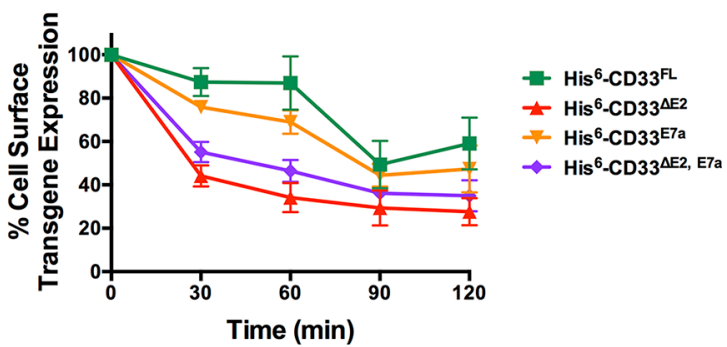
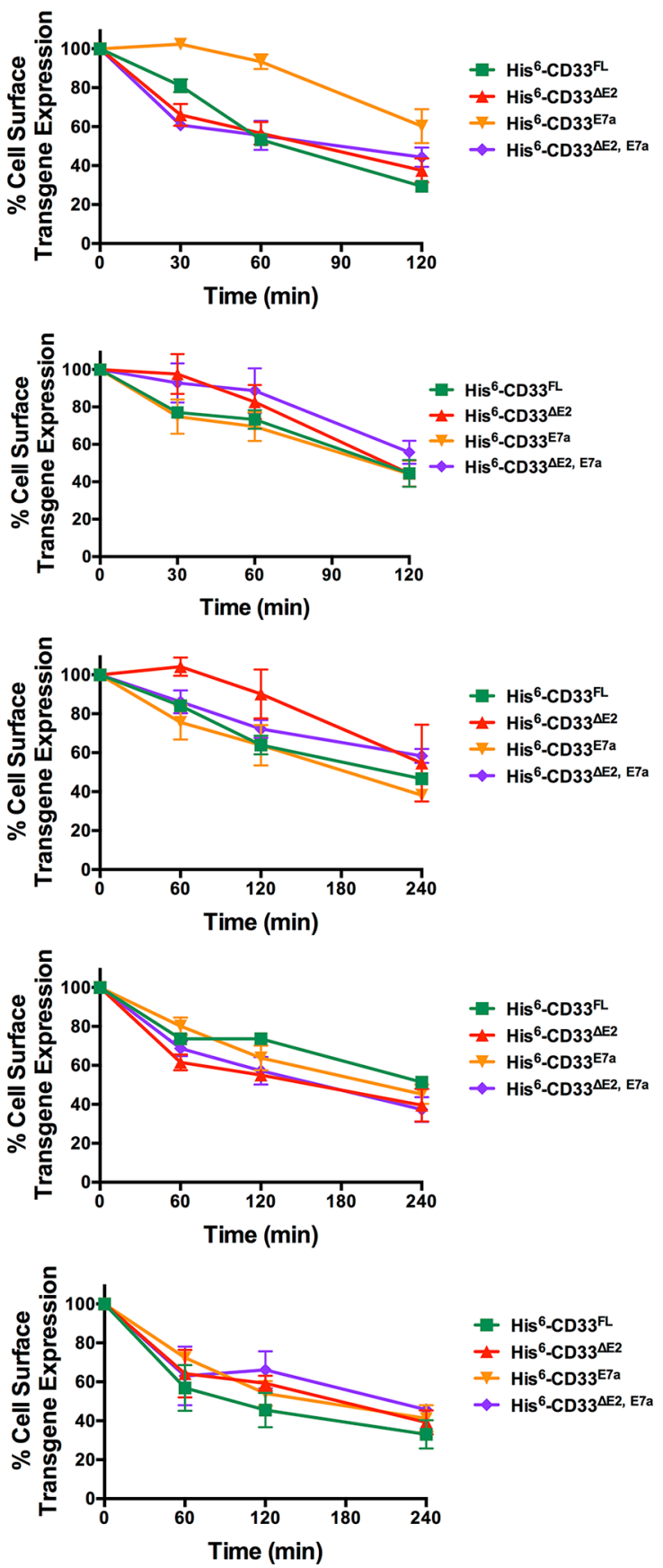

Figure 5: Internalization of CD33 splice variants in engineered acute leukemia cell lines. Parental (A) KG-1a, (B) ML-1, (C) OCI-AML3, (D) RCH-ACV, (E) REH, and (F) RS4;11 cells were transduced with lentiviral particles to express either His-tagged CD33 ${ }^{\mathrm{FL}}$, $\mathrm{CD} 33^{\triangle \mathrm{E} 2}, \mathrm{CD} 33^{\mathrm{E} 7 \mathrm{a}}$, or CD33 ${ }^{\mathrm{AE} 2 \mathrm{E} 7 \mathrm{a}}$. LEFT PANEL: Cell surface display of the tagged transgenes was then quantified flow cyometrically using His antibody, and results expressed as arbitrary median fluorescence units (MFI). RIGHT PANEL: Internalization of His antibody was quantified in aliquots of engineered leukemia cell sublines over 120 or 240 minutes, and shown as percentage of remaining cell surface expression of the CD33 transgene detected at time 0 . Results are depicted as mean \pm SEM from 3 independent experiments. 
differences were not consistent across cell lines but, rather, appeared cell context specific. Specifically, in engineered AML cell lines, a reduced degree of antigen modulation relative to wild-type CD33 was noted in sublines expressing CD33 isoforms containing exon 7a; by comparison, in engineered ALL cell lines, a reduced degree of antigen modulation relative to wild-type CD33 was noted in sublines expressing CD33 isoforms that lack exon 2 (Figure 8).
GO-induced cytotoxicity in human leukemia cell lines expressing CD33 splice variants

As the second characteristic, we studied the cytotoxic properties of the CD33 antibody-drug conjugate GO in parental AML and ALL cell lines and corresponding sublines engineered to express His-tagged CD33 splice variants. As shown in Figure 9, expression of CD33 splice variants that contain the $\mathrm{V}$-set domain recognized by GO
A

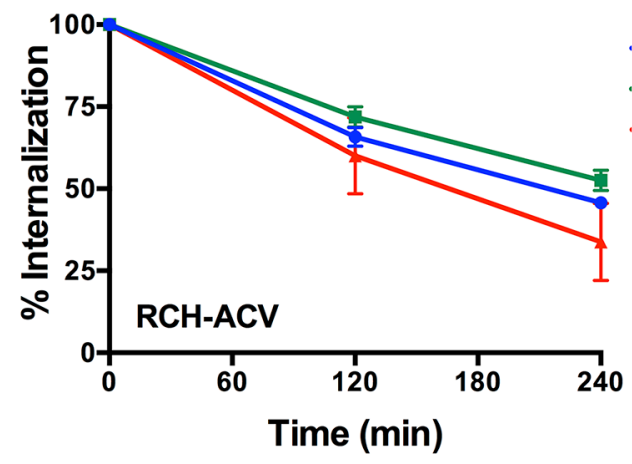

B

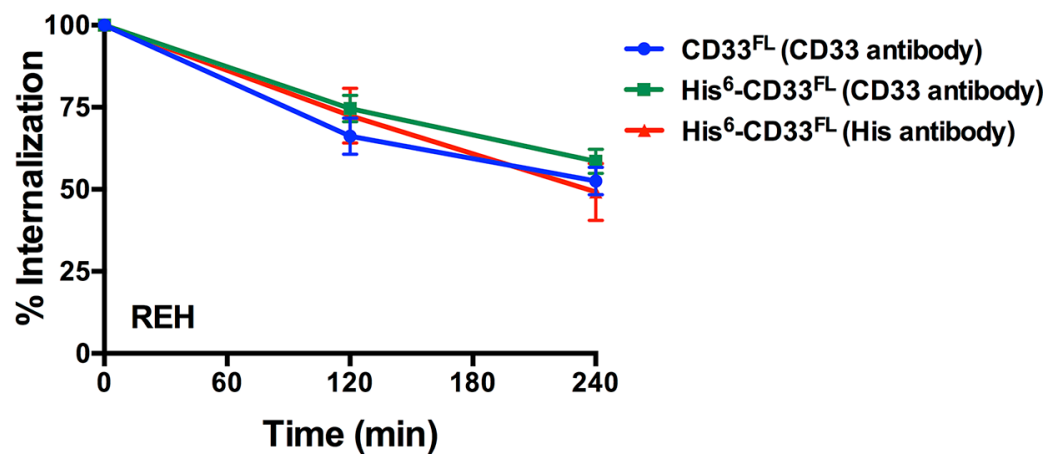

Figure 6: Internalization of antibody-bound CD33. Comparative analysis of the 120-minute and 240-minute internalization of untagged and His-tagged CD33 ${ }^{\mathrm{FL}}$ when bound with CD33 antibody or His antibody in lentivirally-transduced (A) REC-ACV and (B) REH cells. Results are shown as mean \pm SEM from 3 independent experiments.
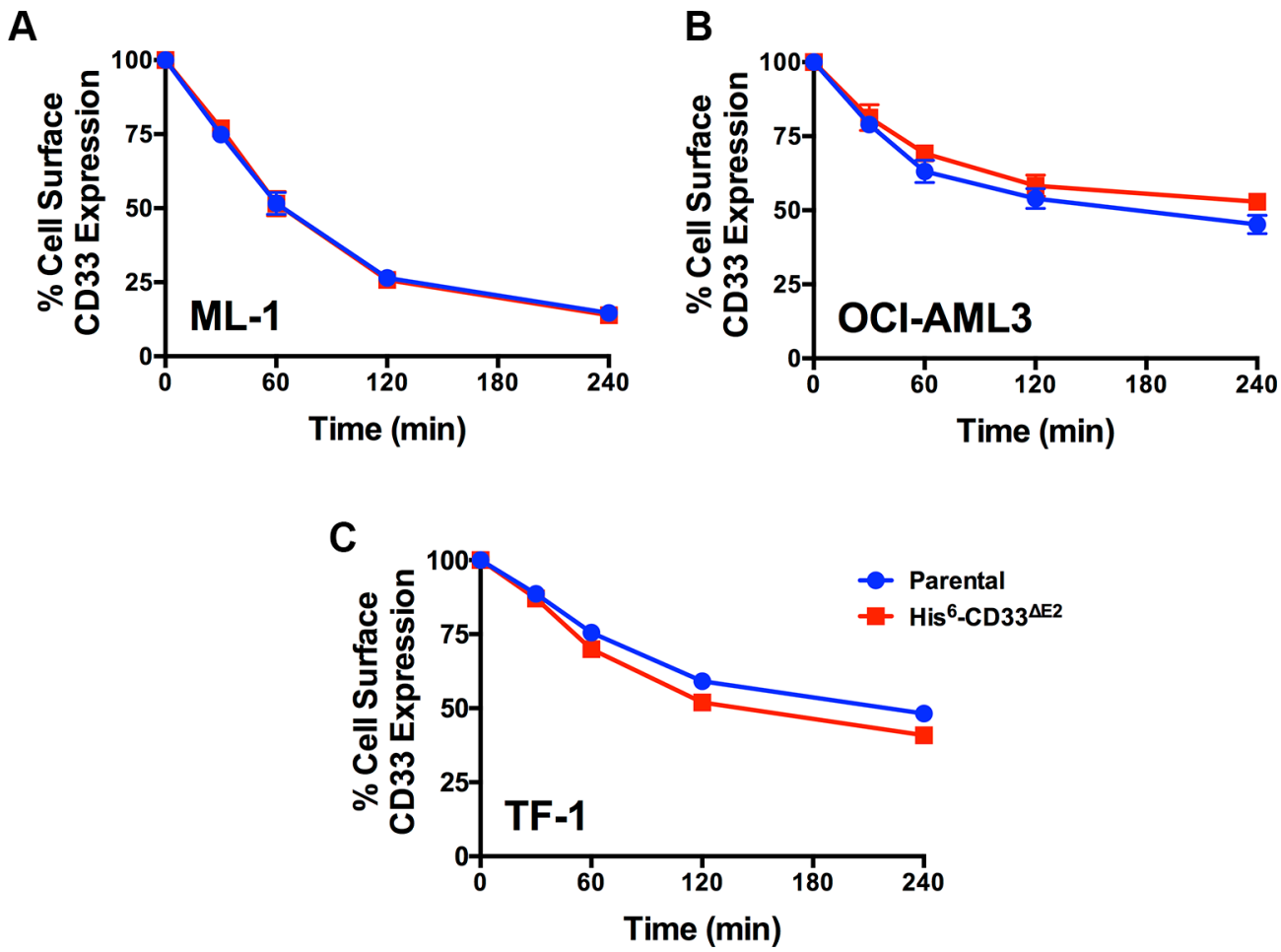

Figure 7: Effect of $\mathbf{C D 3 3}^{\mathrm{AE} 2}$ on internalization of $\mathbf{C D 3 3}^{\mathrm{FL}}$. Parental (A) ML-1, (B) OCI-AML3, and (C) TF-1 cells and their sublines transduced with His-tagged CD33 ${ }^{\triangle \mathrm{E} 2}$ were incubated with CD33 antibody, and internalization of antibody-bound CD33 was then quantified flow cyometrically over 240 minutes and shown as percentage of remaining cell surface expression of CD33 detected at time 0 . Results are depicted as mean \pm SEM from 3 independent experiments. 
$\left(\mathrm{CD} 33^{\mathrm{FL}}\right.$ and $\left.\mathrm{CD} 33^{\mathrm{E} 7 \mathrm{a}}\right)$ sensitized human AML and ALL cell lines to GO-induced cytotoxicity. Consistent with our previous data [13], overexpression of $\mathrm{CD} 33^{\mathrm{FL}}$ increased GO-induced cytotoxicity in AML cell lines (KG-1a, ML-1, and OCI-AML3) that endogenously express CD33. In contrast, expression of CD33 variants that do not contain the $\mathrm{V}$-set domain $\left(\mathrm{CD} 33^{\Delta \mathrm{E} 2}\right.$ and $\mathrm{CD} 33^{\triangle \mathrm{E} 2, \mathrm{E} 7 \mathrm{a}}$ ) did not modulate the cytotoxic effects of GO. Moreover, co-expression of $\mathrm{CD}_{3} 3^{\mathrm{AE} 2}$ did not impact GO-induced cytotoxicity in AML cells endogenously displaying CD33 on the cell surface, as evidenced by our findings in ML-1 and OCI-AML3 cells, indicating that $\mathrm{CD} 33^{\triangle \mathrm{E} 2}$ does not interfere with the ability of $\mathrm{CD} 33^{\mathrm{FL}}$ to serve as carrier for intracellular delivery of cytotoxic drugs to CD33expressing leukemia cells.

\section{DISCUSSION}

The number of antigens exploited for immunotherapy of AML has been increasing rapidly over the last several years [17]. Nonetheless, CD33 remains of great interest for the development of antibody-based therapies. Besides its broad expression in AML, this interest is at least partially due to two circumstances, namely the fact that it thus far represents the only validated target in AML and the fact that GO - the antibody-drug conjugate that provided target validation - is currently not commercially available in most countries [1]. Several new CD33-directed agents, including a second-generation antibody-drug conjugate (SGN-CD33A), a bispecific T-cell engaging (BiTE) antibody (AMG 330), and chimeric antigen receptormodified T-cells have recently entered the clinical phase of drug testing, and others are at various stages of preclinical development.

Because of this ongoing interest in CD33 as an AML target, we sought to better characterize the expression pattern of various forms of CD33 in human AML. Using a large set of diagnostic specimens from patients with AML, our studies demonstrate that in the vast majority of cases, 3 splice variants of CD33 are found in addition to $\mathrm{CD} 33^{\mathrm{FL}}$. One of these variants $\left(\mathrm{CD} 33^{\Delta \mathrm{E} 2}\right)$ has previously been found in normal myeloid cells, microglial cells, T-lymphocytes, and natural killer (NK) cells [8-11, 18], and has been implicated in influencing the susceptibility to Alzheimer's disease $[10,11,18] . \mathrm{CD}^{\mathrm{AE} 2}$ has also been described in several human AML cell lines [9]. We extend these findings by demonstrating that $\mathrm{CD} 33^{\Delta \mathrm{E} 2}$ is present at the mRNA level in the vast majority of primary AML specimens (29 of 29 in our series). Our studies also show the almost universal presence of mRNA corresponding to a CD33 ${ }^{\mathrm{E} 7 \mathrm{a}}$ splice variant (the sequence of which was previously deposited in the genome databases; found in 29 of 29 in our series) and a CD33 ${ }^{\triangle \mathrm{E} 2 \text {,E7a }}$ splice variant (found in 27 of 29 in our series), which has so far not been described.

Exon 2 encodes the ligand-binding extracellular $\mathrm{V}$-set domain of CD33, and CD33 proteins lacking this exon are expected to feature functional properties that differ from those of wild-type CD33. Indeed, previous studies have indicated that $\mathrm{CD} 33^{\mathrm{FL}}$ but not $\mathrm{CD} 33^{\triangle \mathrm{E} 2}$
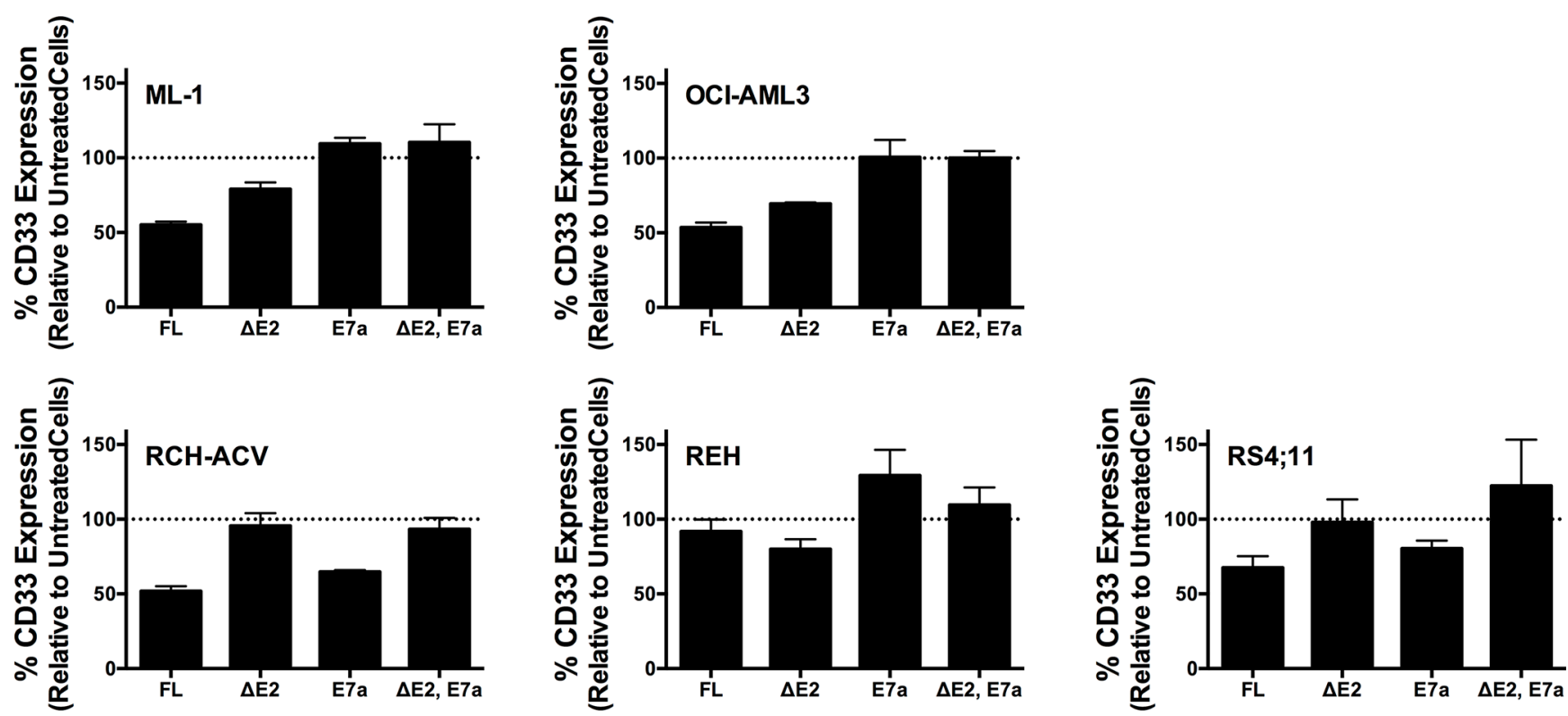

Figure 8: CD33 modulation in engineered acute leukemia cells. Comparative analysis of the modulation of His-tagged $\mathrm{CD} 33^{\mathrm{FL}}$, $\mathrm{CD}^{\triangle \mathrm{EE} 2}, \mathrm{CD} 33^{\mathrm{E} 7 \mathrm{a}}$, or CD33 ${ }^{\triangle \mathrm{E} 2, \mathrm{E} 7 \mathrm{a}}$ in lentivirally-transduced AML cells (ML-1, OCI-AML3) and ALL cells (RCH-ACV, REH, RS4;11). Cells were incubated for 24 hours with His antibody followed by incubation with a biotin-anti-mouse secondary antibody and APCstreptavidin. Results are shown as mean \pm SEM from 3 independent experiments. 
inhibits uptake and clearance of insoluble, toxic amyloid $\beta$ species by microglial cells in vitro - an activity that may be important for the pathogenesis of Alzheimer's disease [19]. These studies have identified CD33 as a potential target for the treatment and/or prevention of Alzheimer's disease [19]. In this situation, blocking CD33 isoforms that contain exon 2 and have functional activity may be sufficient. For the treatment of CD33+ malignancies, however, directing the therapeutic toward all CD33 isoforms displayed on the cell surface may be advantageous since it would provide the greatest possible abundance of antibody binding sites. Consistent with previous reports $[9,19]$, we found that CD33 variants lacking exon 2 can be expressed on the cell surface, although our studies indicate that the efficiency with which this happens varies between different cell line backgrounds. Similar to wild-type CD33, our experiments in engineered acute leukemia cell lines document that the $\mathrm{CD} 33^{\Delta \mathrm{E} 2}$ variant is internalized, and could thus also serve as target for CD33-directed therapeutics that depend on intracellular delivery of a toxic payload.

Our studies in lentivirally-transduced acute leukemia cell lines also show that the CD33 variants that contain exon $7 \mathrm{a}$, and therefore lack almost the entire cytoplasmic tail of CD33, are internalized. At first glance, this is surprising since we previously found CD33 endocytosis to be controlled by the intracellular domain of CD33. Introduction of point mutations in this domain, for example in the immunoreceptor tyrosinebased inhibitory motifs or clusters of lysine residues, reduced internalization of antibody/CD33 complexes in our earlier studies $[13,15]$. Whether the cell membrane localization is influenced by the presence of the cytoplasmic tail of CD33, and whether the mechanistic principles for the uptake process differ between wildtype CD33 and variants that contain exon $7 \mathrm{a}$, is currently unknown and will be subject of future investigations. The cell context-specific differences we found with regard to modulation of individual CD33 variants would be consistent with such differences in membrane localization and/or internalization mechanisms. Planned studies will also aim to identify differences between CD33 variants containing exon $7 \mathrm{a}$ with wild-type protein with regard to suppression of myeloid cell function - we hypothesize that such differences exist given the lack of immunoreceptor tyrosine-based inhibitory motifs when exon $7 \mathrm{a}$ is utilized.

In summary, our studies demonstrate the presence of 3 splice variants of CD33 that have endocytic properties when bound by a bivalent antibody in almost all patients with AML. These findings document a greater-thanpreviously thought complexity of CD33 expression in human AML. Furthermore, they identify CD33 variants that lack exon 2 and are not recognized by currently explored CD33-directed therapeutics as potential, hitherto unexploited, targets for immunotherapy with unconjugated or conjugated CD33 antibodies.
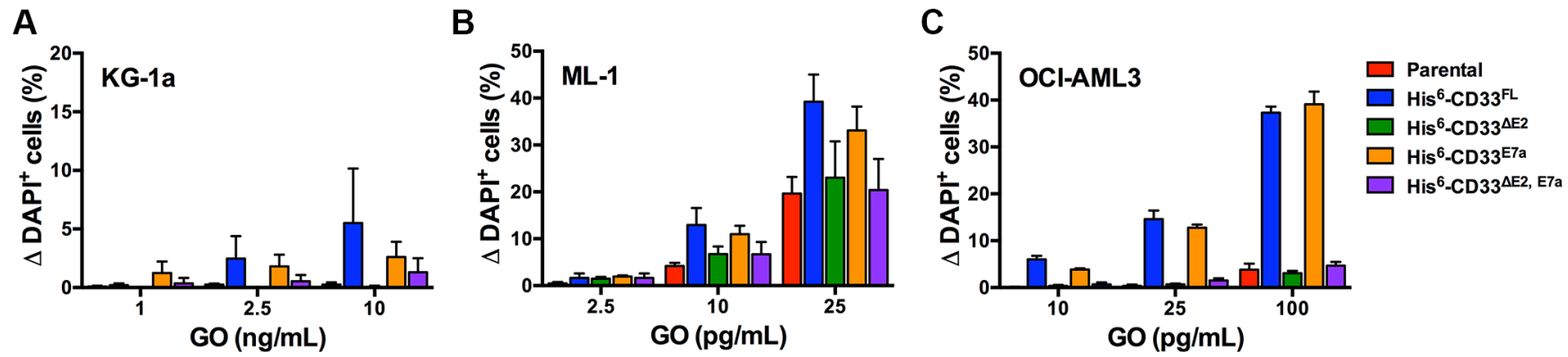

D

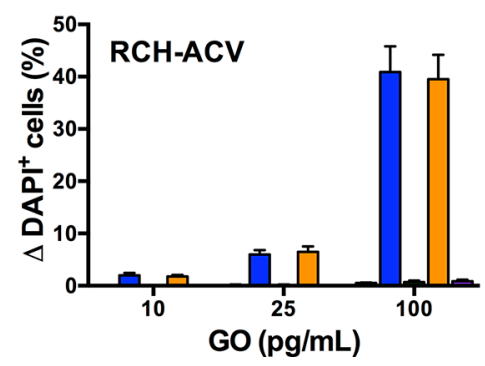

E

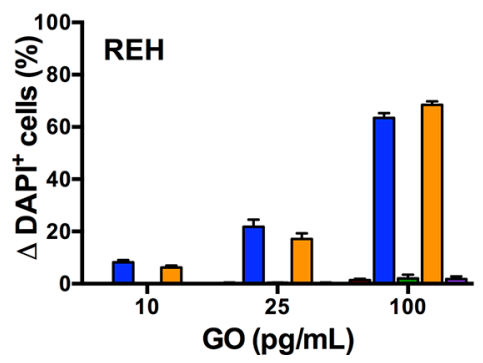

$\mathbf{G}$

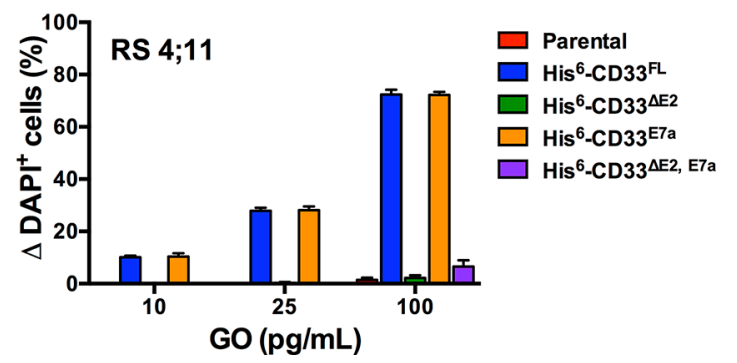

Figure 9: Effect of CD33 splice variants on GO-induced cytotoxicity. Parental (A) KG-1a, (B) ML-1, (C) OCI-AML3,

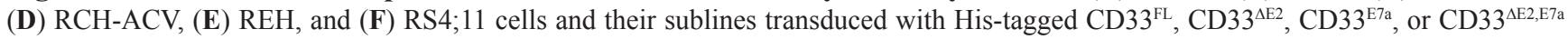
were then incubated with various concentrations of GO for 3 days before cytotoxicity was assessed with DAPI staining. Increases in the percentage of $\mathrm{DAPI}^{+}$cells in GO-treated cells are compared to corresponding cells that were incubated without GO, and results are shown as mean \pm SEM from 3 independent experiments performed in duplicate wells. 


\section{MATERIALS AND METHODS}

\section{Transcriptome sequencing of primary AML specimens}

Sixty-eight patients with newly diagnosed AML enrolled on 2 recent $\mathrm{COG}$ trials were selected for retrospective whole transcriptome RNA sequencing (RNAseq) because they lacked known high-risk cytogenetic features but eventually relapsed [20]. Total RNA from pre-treatment bone marrow or peripheral blood specimens was used to generate a cDNA library, which was purified and enriched by polymerase chain reaction (PCR) amplification and subjected to 50-cycle pairedend sequencing on the Illumina HiSeq as previously described [20]. RNA sequencing reads were then aligned to the human genome to identify splice junctions between exons and identify new gene variants using TopHat [21]. Informed consent was obtained in accordance with the Declaration of Helsinki. The institutional review boards (IRBs) of all participating institutions approved the clinical protocol, while the Fred Hutchinson Cancer Research Center (Fred Hutch) IRB and the COG Myeloid Disease Biology Committee approved this research study.

\section{PCR-based detection of CD33 splice variant expression in primary AML specimens}

Frozen aliquots of Ficoll-isolated mononuclear cells from pretreatment specimens (bone marrow $[n=13]$, peripheral blood $[n=14]$, or apheresis $[n=2]$ ) from 29 adults with newly diagnosed $(n=17)$ or relapsed/ refractory $(n=12)$ AML were obtained from Fred Hutch AML cell repositories and selected for inclusion based on the presence of a large number of myeloblasts (median: 87.4\%; range: $38.6-95.1 \%$; Table 1). We used the refined United Kingdom Medical Research Council/National Cancer Research Institute (MRC/NCRI) criteria to assign cytogenetic risk [22]. Patients provided written informed consent for the collection and use of their specimens for research purposes under an IRB-approved protocol. Genetic material was extracted using AllPrep DNA/ RNA Mini Kits (Qiagen, Valencia, CA). Approximately $25 \mathrm{ng}$ of RNA was then reverse transcribed for each PCR reaction with specific primers to amplify $\mathrm{CD} 33^{\mathrm{FL}}$, $\mathrm{CD} 33^{\triangle \mathrm{E} 2}, \mathrm{CD} 33^{\mathrm{E} 7 \mathrm{a}}$, and $\mathrm{CD} 33^{\triangle \mathrm{E} 2 \mathrm{E} \mathrm{E} 7 \mathrm{a}}$ (see Table 2 for primer sequences). Amplicons were electrophoretically separated in $0.9 \%$ agarose gel and visualized with ethidium bromide (AlphaImager HP; ProteinSimple, San Jose, CA, USA). Selected amplicons were subjected to Applied Biosystems (ABI) BigDye ${ }^{\mathrm{TM}}$ Terminator sequencing.

\section{Generation of lentiviral vectors expressing CD33 constructs}

A pRRLsin.cPPT.MSCV lentivirus containing a human $\mathrm{CD} 33^{\mathrm{FL}}$ in conjunction with an internal ribosomal entry site (IRES)/Enhanced Green Fluorescent Protein (EGFP) cassette has previously been described [13, 23]. Human cDNAs corresponding to $\mathrm{CD} 33^{\mathrm{FL}}$ with an N-terminal hexahistidine (His), and the $\mathrm{CD} 33^{\mathrm{\triangle E} 2}, \mathrm{CD} 33^{\mathrm{E} 7 \mathrm{a}}$, and $\mathrm{CD} 33^{\triangle \mathrm{E} 2 \mathrm{E7} \mathrm{Ea}}$ variants with or without an N-terminal His tag were generated in TOPO vectors via standard PCR cloning procedures (see Table 3 for primer sequences), verified by sequencing, and subsequently transferred into the pRRLsin.cPPT.MSCV vector. Lentiviral particles were prepared as described previously [13].

\section{Parental and engineered human cell lines}

Human myeloid KG-1a cells (kindly provided by Dr. Derek L. Stirewalt; Fred Hutch, Seattle, WA), OCI-AML3 cells (kindly provided by Dr. Soheil Meshinchi; Fred Hutch), and ML-1 as well as TF-1 cells (kindly provided by Dr. Irwin D. Bernstein; Fred Hutch) were maintained as previously described [13, 24, 25]. Human lymphoid RCH-ACV and REH cells (kindly provided by Dr. Jerald P. Radich; Fred Hutch) were maintained in RPMI-1640 medium (Life Technologies, Grand Island, NY) with 10\% fetal bovine serum (FBS; HyClone, Thermo Scientific, Logan, UT), and RS4;11 cells were maintained in MEM Alpha (Life Technologies) with 10\% FBS. Human embryo kidney (HEK)293T cells (kindly provided by Dr. Jonathan A. Cooper; Fred Hutch) were maintained in DMEM medium (Life Technologies) with 10\% FBS. All cell lines were confirmed to be mycoplasma-free but were not recently authenticated. Sublines of these cell lines overexpressing individual tagged or untagged CD33 constructs were generated through transduction with the appropriate $\mathrm{pRRL}$ sin.cPPT.MSCV lentiviral particles at a multiplicity of infection (MOI) of 25. EGFP-positive cells were isolated by flow cytometry and re-cultured for further analysis.

\section{Quantification of CD33 expression}

Expression of untagged CD33 variants on leukemia cell lines was quantified by flow cytometry using an unconjugated CD33 antibody (clone P67.6; BD Biosciences, San Jose, CA, USA) [13, 23] or unconjugated CD33 antibody followed by a biotin-anti-mouse secondary antibody and APC-streptavidin (both BD Biosciences). In some cases, a second CD33 antibody (clone HIM3-4) previously reported to recognize the $\mathrm{C} 2$-set Ig-like domain of CD33 [9] was used to detect cell surface display of CD33 variants. Expression of hexahistidine-tagged CD33 proteins was determined using an antibody against THE ${ }^{\mathrm{TM}}$ His tag (clone 6G2A9; GenScript, Piscataway, NJ, USA) followed by a biotin-anti-mouse secondary antibody and APC-streptavidin. To identify nonviable cells, samples were stained with 4',6-diamidino-2-phenylindole (DAPI). 10,000 events were acquired on a BD FACSCanto II flow cytometer (BD Biosciences), and DAPI- cells analyzed using FlowJo (Tree Star, Ashland, OR). 
Table 2: List of primers to detect CD33 splice variants

\begin{tabular}{|c|c|}
\hline CD33 variant & Primer sequences \\
\hline $\mathrm{CD} 33^{\mathrm{FL}}$ & $\begin{array}{l}\text { For: 5'-TGGCTATGGATCCAAATTTCTGGCTG-3' (annealing to exon 2) } \\
\text { Rev: 5'-AGCATAATGCAGCTCCTCATC-3' (annealing to exon 7b) }\end{array}$ \\
\hline $\mathrm{CD} 3^{\triangle \mathrm{E} 2}$ & $\begin{array}{l}\text { For: 5'-CCTGCTGTGGGCAGACTTGAC-3' (annealing to junction of exon 1/exon 3) } \\
\text { Rev: 5'-AGCATAATGCAGCTCCTCATC-3' (annealing to exon } 7 \mathrm{~b} \text { ) }\end{array}$ \\
\hline $\mathrm{CD} 33^{\mathrm{E} 7 \mathrm{a}}$ & $\begin{array}{l}\text { For: 5'-TGGCTATGGATCCAAATTTCTGGCTG-3' (annealing to exon 2) } \\
\text { Rev: 5'-GATTGCAGGTGTGAAACACTG-3' (annealing to exon 7a) }\end{array}$ \\
\hline $\mathrm{CD} 33^{\Delta \mathrm{E} 2, \mathrm{E} 7 \mathrm{a}}$ & $\begin{array}{l}\text { For: 5'-CCTGCTGTGGGCAGACTTGAC-3' (annealing to junction of exon 1/exon 3) } \\
\text { Rev: 5'-GATTGCAGGTGTGAAACACTG-3' (annealing to exon 7a) }\end{array}$ \\
\hline
\end{tabular}

Table 3: List of mutagenesis primers

\begin{tabular}{|c|c|}
\hline Construct & Primer sequences \\
\hline $\mathrm{CD} 33^{\mathrm{FL} / \mathrm{His}}$ & $\begin{array}{l}\text { For: 5'-CATCATCACCATCACCACGGAGGTGGAATGGATCCAAATTTCTGGCTGC-3' } \\
\text { Rev: 5'-TCCACCTCCGTGGTGATGGTGATGATGAGCCAGGGCCCCTGC-3' }\end{array}$ \\
\hline $\mathrm{CD} 33^{\triangle \mathrm{E} 2}$ & $\begin{array}{l}\text { For: 5'-TGCCCCTGCTGTGGGCAGACTTGACCCACAGGCCC-3' } \\
\text { Rev: 5'-GGGCCTGTGGGTCAAGTCTGCCCACAGCAGGGGCA-3' }\end{array}$ \\
\hline $\mathrm{CD} 33^{\Delta \mathrm{E} 2 / \mathrm{His}}$ & $\begin{array}{l}\text { For: 5'-CATCATCACCATCACCACGGAGGTGGACCCAAAATCCTCATCCCTG-3' } \\
\text { Rev: 5'-TCCACCTCCGTGGTGATGGTGATGATGCCTGTGGGTCAAGTCTGC-3' }\end{array}$ \\
\hline $\begin{array}{l}\mathrm{CD} 33^{\mathrm{E} 7 \mathrm{a}}, \mathrm{CD} 33^{\mathrm{E} 7 \mathrm{a} / \mathrm{His}} \\
\mathrm{CD} 33^{\Delta \mathrm{E} 2 \mathrm{E7},}, \mathrm{CD} 33^{\Delta \mathrm{E} 2, \mathrm{E} 7 \mathrm{Fa} / \mathrm{is}}\end{array}$ & $\begin{array}{l}\text { For: 5'-ATGCCGCTGCTGCTACTGCTGC-3' } \\
\text { Rev: 5'-TCAACGTACCGGGGAGGCTGACCCTGTGGTAG-3' }\end{array}$ \\
\hline
\end{tabular}

\section{Quantification of CD33 internalization and modulation}

To measure internalization of antibody-bound CD33, cells (typically $1-1.5 \times 10^{6}$ ) were transferred into $15 \mathrm{~mL}$ polypropylene conical bottom tubes $\left(\mathrm{Falcon}^{\mathrm{TM}}\right.$, Corning Life Sciences, Tewksbury, MA, USA) and incubated for at least 20 minutes with phosphate buffered saline (PBS, GIBCO by Life Technologies) $/ 2 \%$ FBS containing $2.5 \mu \mathrm{g} / \mathrm{mL}$ unconjugated P67.6 (Santa Cruz Biotechnology, Dallas, TX, USA) or His tag antibody in ice-water (to prevent internalization during the staining procedure), as appropriate. Cells were then washed in ice-cold PBS, resuspended in IMDM medium without antibody, split into several tubes, and incubated at $37^{\circ} \mathrm{C}$ (in $5 \% \mathrm{CO}_{2}$ and air) for various periods of time. Afterwards, cells were chilled and incubated with biotin-conjugated rat anti-mouse $\operatorname{IgG}_{1}$ monoclonal antibody (used at $2.5 \mu \mathrm{g} / \mathrm{mL}$ in $\mathrm{PBS} / 2 \% \mathrm{FBS}$ ), followed by incubation with streptavidin-APC conjugate (used at $2.5 \mu \mathrm{g} / \mathrm{mL}$ in PBS/2\% FBS: both from BD Biosciences, San Jose, CA, USA) to detect remaining primary antibody on the cell surface. One sample that was kept in ice water was used to determine the starting level of antibody bound to the cell surface. To determine CD33 modulation, aliquots of engineered leukemia cells were left untreated or incubated with unlabeled His tag antibody (used at $2.5 \mu \mathrm{g} / \mathrm{mL}$ ). After 24 hours, cells were washed in ice-cold PBS to remove unbound antibody and resuspended in $\mathrm{PBS} / 2 \% \mathrm{FBS}$. Aliquots of untreated and antibody-treated cells were then incubated with His antibody (to saturate binding sites) or no antibody followed by biotin-conjugated rat anti-mouse $\mathrm{IgG}_{1}$ (used at $2.5 \mu \mathrm{g} / \mathrm{mL}$ in $\mathrm{PBS} / 2 \%$ FBS) and streptavidin-APC (used at $2.5 \mu \mathrm{g} / \mathrm{mL}$ in $\mathrm{PBS} / 2 \% \mathrm{FBS}$ ). For analysis, all samples were stained with DAPI to identify nonviable cells; at least 10,000 events were acquired, and DAPI- cells were analyzed on a BD FACSCanto II flow cytometer using FlowJo. Linear fluorescence values were used to calculate the percentage of CD33 internalization or modulation.

\section{Quantification of drug-induced cytotoxicity}

AML cells were incubated at $37^{\circ} \mathrm{C}$ (in $5 \% \mathrm{CO}_{2}$ and air) in 96-well round bottom plates (Falcon ${ }^{\mathrm{TM}}$ ) at $8 \times 10^{3}$ cells/well in $200 \mu \mathrm{L}$ culture medium containing various concentrations of gemtuzumab ozogamicin (commercially obtained from Pfizer, New York, NY). After 72 hours, cell numbers and drug-induced cytotoxicity, using DAPI to detect non-viable cells, were determined using a BDFACSCanto II flow cytometer and analyzed with FlowJo software.

\section{ACKNOWLEDGMENTS}

We thank the Fred Hutch Co-operative Center of Excellence in Hematology (CCEH) Vector Production core facility for preparing lentiviral particles and the COG AML Reference Laboratory for providing diagnostic AML specimens. 


\section{CONFLICTS OF INTEREST}

R.B.W. has received research funding from Amgen, Inc., Amphivena Therapeutics, Inc., Covagen AG, Emergent Biosolutions, Inc., Pfizer, Inc., and Seattle Genetics, Inc and Seattle Genetics, Inc., and is a consultant for Amphivena Therapeutics, Inc, and Covagen AG. The other authors declare no competing financial interests.

\section{GRANT SUPPORT}

Supported by grants R21-CA1555524, R01CA114563, U01-CA176270, and U10-CA180886 from the National Cancer Institute/National Institutes of Health (NCI/NIH), P30-DK056465 (CCEH) from the National Institute of Diabetes and Digestive and Kidney Diseases/NIH, an Innovation Grant from the Alex's Lemonade Stand Foundation, and a Translational Research Program grant from the Leukemia \& Lymphoma Society (6489-16). R.B.W. is a Leukemia \& Lymphoma Society Scholar in Clinical Research (2311-15).

\section{REFERENCES}

1. Laszlo GS, Estey EH, Walter RB. The past and future of CD33 as therapeutic target in acute myeloid leukemia. Blood Rev. 2014; 28:143-153.

2. Macauley MS, Crocker PR, Paulson JC. Siglec-mediated regulation of immune cell function in disease. Nat Rev Immunol. 2014; 14:653-666.

3. Angata T, Nycholat CM, Macauley MS. Therapeutic Targeting of Siglecs using Antibody- and Glycan-Based Approaches. Trends Pharmacol Sci. 2015; 36:645-660.

4. Walter RB, Appelbaum FR, Estey EH, Bernstein ID. Acute myeloid leukemia stem cells and CD33-targeted immunotherapy. Blood. 2012; 119:6198-6208.

5. Hills RK, Castaigne S, Appelbaum FR, Delaunay J, Petersdorf S, Othus M, Estey EH, Dombret H, Chevret S, Ifrah N, Cahn JY, Recher C, Chilton L, et al. Addition of gemtuzumab ozogamicin to induction chemotherapy in adult patients with acute myeloid leukaemia: a meta-analysis of individual patient data from randomised controlled trials. The Lancet Oncology. 2014; 15:986-996.

6. Gamis AS, Alonzo TA, Meshinchi S, Sung L, Gerbing RB, Raimondi SC, Hirsch BA, Kahwash SB, HeeremaMcKenney A, Winter L, Glick K, Davies SM, Byron P, et al. Gemtuzumab ozogamicin in children and adolescents with de novo acute myeloid leukemia improves eventfree survival by reducing relapse risk: results from the randomized phase III Children's Oncology Group trial AAML0531. J Clin Oncol. 2014; 32:3021-3032.

7. Simmons D, Seed B. Isolation of a cDNA encoding CD33, a differentiation antigen of myeloid progenitor cells. J Immunol. 1988; 141:2797-2800.

8. Hernández-Caselles T, Martínez-Esparza $\mathrm{M}$, PérezOliva AB, Quintanilla-Cecconi AM, García-Alonso A,
Alvarez-López DM, García-Peñarrubia P. A study of CD33 (SIGLEC-3) antigen expression and function on activated human T and NK cells: two isoforms of CD33 are generated by alternative splicing. J Leukoc Biol. 2006; 79:46-58.

9. Pérez-Oliva AB, Martínez-Esparza $\mathrm{M}$, VicenteFernández JJ, Corral-San Miguel R, García-Peñarrubia P, Hernández-Caselles T. Epitope mapping, expression and post-translational modifications of two isoforms of CD33 (CD33M and CD33m) on lymphoid and myeloid human cells. Glycobiology. 2011; 21:757-770.

10. Malik M, Simpson JF, Parikh I, Wilfred BR, Fardo DW, Nelson PT, Estus S. CD33 Alzheimer's risk-altering polymorphism, CD33 expression, and exon 2 splicing. J Neurosci. 2013; 33:13320-13325.

11. Raj T, Ryan KJ, Replogle JM, Chibnik LB, Rosenkrantz L, Tang A, Rothamel K, Stranger BE, Bennett DA, Evans DA, De Jager PL, Bradshaw EM. CD33: increased inclusion of exon 2 implicates the Ig V-set domain in Alzheimer's disease susceptibility. Hum Mol Genet. 2014; 23:2729-2736.

12. Peiper SC, Leboeuf RD, Hughes CB, Prasthofer EF, Borowitz MJ, Dewutter-Dambuyant C, Katz DR, Walker WS, Ashmun RA, Look AT. Report on the CD33 cluster workshop: biochemical and genetic characterization of gp67. In: Knapp W, Dörken B, Gilks WR, Rieber EP, Schmidt RE, Stein H and von dem Borne EAGK, eds. Leukocyte Typing IV: White Cell Differentiation Antigens. (Oxford, UK: Oxford University Press). 814-816.

13. Walter RB, Raden BW, Kamikura DM, Cooper JA, Bernstein ID. Influence of CD33 expression levels and ITIMdependent internalization on gemtuzumab ozogamicininduced cytotoxicity. Blood. 2005; 105:1295-1302.

14. Walter RB, Raden BW, Zeng R, Häusermann $P$, Bernstein ID, Cooper JA. ITIM-dependent endocytosis of CD33-related Siglecs: role of intracellular domain, tyrosine phosphorylation, and the tyrosine phosphatases, Shp 1 and Shp2. J Leukoc Biol. 2008; 83:200-211.

15. Walter RB, Hausermann P, Raden BW, Teckchandani AM, Kamikura DM, Bernstein ID, Cooper JA. Phosphorylated ITIMs enable ubiquitylation of an inhibitory cell surface receptor. Traffic. 2008; 9:267-279.

16. Paul SP, Taylor LS, Stansbury EK, McVicar DW. Myeloid specific human CD33 is an inhibitory receptor with differential ITIM function in recruiting the phosphatases SHP-1 and SHP-2. Blood. 2000; 96:483-490.

17. Buckley SA, Walter RB. Antigen-specific immunotherapies for acute myeloid leukemia. Hematology Am Soc Hematol Educ Program. 2015; 2015:584-595.

18. Schwarz F, Springer SA, Altheide TK, Varki NM, Gagneux P, Varki A. Human-specific derived alleles of CD33 and other genes protect against postreproductive cognitive decline. Proc Natl Acad Sci U S A. 2016; 113:74-79.

19. Griciuc A, Serrano-Pozo A, Parrado AR, Lesinski AN, Asselin CN, Mullin K, Hooli B, Choi SH, Hyman BT, Tanzi RE. Alzheimer's disease risk gene CD33 inhibits 
microglial uptake of amyloid beta. Neuron. 2013; 78:631-643.

20. Walter RB, Laszlo GS, Alonzo TA, Gerbing RB, Levy $\mathrm{S}$, Fitzgibbon MP, Gudgeon CJ, Ries RE, Harrington KH, Raimondi SC, Hirsch BA, Gamis AS, M WM, et al. Significance of expression of ITGA5 and its splice variants in acute myeloid leukemia: a report from the Children's Oncology Group. Am J Hematol. 2013; 88:694-702.

21. Trapnell C, Pachter L, Salzberg SL. TopHat: discovering splice junctions with RNA-Seq. Bioinformatics. 2009; 25:1105-1111.

22. Grimwade D, Hills RK, Moorman AV, Walker H, Chatters S, Goldstone AH, Wheatley K, Harrison CJ, Burnett AK. Refinement of cytogenetic classification in acute myeloid leukemia: determination of prognostic significance of rare recurring chromosomal abnormalities among 5876 younger adult patients treated in the United Kingdom Medical Research Council trials. Blood. 2010; 116:354-365.
23. Laszlo GS, Gudgeon CJ, Harrington KH, Dell'Aringa J, Newhall KJ, Means GD, Sinclair AM, Kischel R, Frankel SR, Walter RB. Cellular determinants for preclinical activity of a novel CD33/CD3 bispecific T-cell engager (BiTE) antibody, AMG 330, against human AML. Blood. 2014; 123:554-561.

24. Walter RB, Raden BW, Hong TC, Flowers DA, Bernstein ID, Linenberger ML. Multidrug resistance protein attenuates gemtuzumab ozogamicin-induced cytotoxicity in acute myeloid leukemia cells. Blood. 2003; 102:1466-1473.

25. Walter RB, Raden BW, Cronk MR, Bernstein ID, Appelbaum FR, Banker DE. The peripheral benzodiazepine receptor ligand PK11195 overcomes different resistance mechanisms to sensitize AML cells to gemtuzumab ozogamicin. Blood. 2004; 103:4276-4284. 